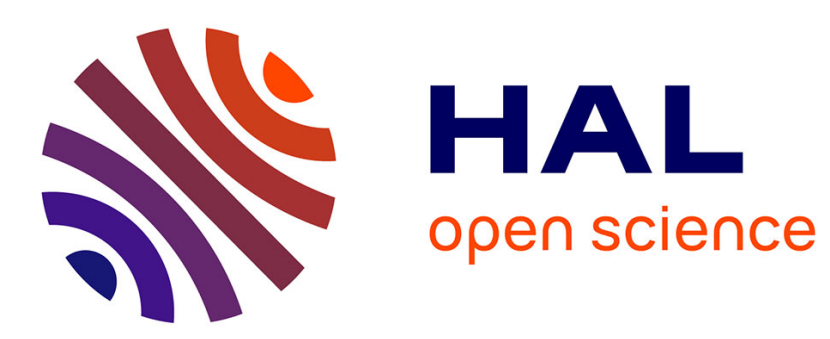

\title{
In Situ Studies of Zeotype Materials Under Operating Conditions
}

\author{
G. Sankar, J. Thomas, G. Greaves, A. Dent
}

\section{To cite this version:}

G. Sankar, J. Thomas, G. Greaves, A. Dent. In Situ Studies of Zeotype Materials Under Operating Conditions. Journal de Physique IV Proceedings, 1997, 7 (C2), pp.C2-871-C2-873. 10.1051/jp4:1997262 . jpa-00255345

\section{HAL Id: jpa-00255345 https://hal.science/jpa-00255345}

Submitted on 1 Jan 1997

HAL is a multi-disciplinary open access archive for the deposit and dissemination of scientific research documents, whether they are published or not. The documents may come from teaching and research institutions in France or abroad, or from public or private research centers.
L'archive ouverte pluridisciplinaire HAL, est destinée au dépôt et à la diffusion de documents scientifiques de niveau recherche, publiés ou non, émanant des établissements d'enseignement et de recherche français ou étrangers, des laboratoires publics ou privés. 


\title{
In Situ Studies of Zeotype Materials Under Operating Conditions
}

\author{
G. Sankar, J.M. Thomas, G.N. Greaves* and A.J. Dent* \\ Davy Faraday Research Laboratory, The Royal Institution of GB, 21 Albemarle Street, London W1X 4BS, \\ $U K$ \\ CCLRC, Daresbury Laboratory, Daresbury, Warrington Cheshire WA4 4AD, UK
}

\begin{abstract}
The power of in situ combined XRD/XAS technique in tracking the formation of microporous solid acid catalyst and the generation of active sites particularly by taking examples of cobalt substituted aluminophosphates is demonstrated.
\end{abstract}

\section{INTRODUCTION}

Heterovalent ions substituted aluminophosphates (divalent in place of $\mathrm{Al}^{3+}$ or tetravalent for $\mathrm{P}^{5+}$ ) or trivalent (for eg. $\mathrm{Al}^{3+}$ or $\mathrm{Fe}^{3+}$ or $\mathrm{Ga}^{3+}$ in place of $\mathrm{Si}^{4+}$ ) ions in substituted zeolites[1] have been shown to be efficient catalysts for Brønsted acid catalysed reactions. Furthermore, some of the framework-incorporated divalent ions such as $\mathrm{Co}^{2+}$ or $\mathrm{Mn}^{2+}$ are known to exhibit oxidation-reduction properties thereby introducing a new dimension to the catalytic performance. Although only relatively small amounts of these heterovalent substituents have been achieved (of the order of 2 wt\%), they nevertheless produce highly active catalytic centres. Understanding the overall framework structure of these microporous solid acid catalysts on the one hand, and the local structure around the hetero atoms on the other, allows the precise description of these shape selective catalysts. It was demonstrated earlier that the combined use of the XRD/XAS techniques enhances our understanding of the structure of various active catalysts[2-5]. In addition, insights into their stability (retention of microporous structure) and oxidation-reduction properties[6,7] are also gained. Here we show how the combined XRD/XAS permits us to characterise zeotype materials under operating conditions either during hydrothermal synthesis or during the activation of the solid acid catalysts.

\subsection{EXPERIMENTAL}

In situ combined XRD/XAS measurements were carried out at station 9.3 of Daresbury Laboratory employing a specially designed cell that permits the measurement of fluorescence and transmission EXAFS as well as XRD data. Details of the in situ cell and the conditions employed are described elsewhere[6,8]

\subsection{RESULTS AND DISCUSSION}

Here we show results of the combined XRD/QuEXAFS measurements demonstrating the power of this technique in characterising materials under operating (non-ambient) conditions. For this purpose, we have chosen two examples. First, the crystallisation of microporous CoAlPO-5 catalyst from its nutrient gel-mother liquor[8] and second, the generation of active sites during activation process of a solid acid catalyst, CoAlPO-18[6].

Synthesis of COAlPO-5: The XRD pattern (figure 1(a)) shows initially a broad hump typical of amorphous nature of the nutrient gel comprised of aluminium hydroxide, phosphoric acid, cobalt acetate and triethylamine (organic template). As the temperature was increased above $170^{\circ} \mathrm{C}$ reflections associated with the AlPO-5 structure starts to appear indicating the onset of crystallisation. It is rather interesting to see that both the pre-edge and main absorption edge intensities of the cobalt K-edge XANES (shown in figure 1(b)) change just prior to crystallisation. This increase in pre-edge intensity and decrease in main absorption (a well known phenomena in many other systems[9]) reflects the change from octahedral (in the cobalt acetate) to tetrahedral (cobalt after incorporation into the framework) coordination. This is corroborated not only by the colour change from pink to blue, but also from the detailed analysis of the EXAFS data which clearly shows a decrease in both coordination number ( 6 to 4$)$ and $\mathrm{Co}-\mathrm{O}$ distance $(2.06 \AA$ to $1.93 \AA)$.

Active site generation in CoAlPO-18: In our earlier study, it was pointed out that CoAlPO-18 retains its porous structure (from XRD) as well as undergoes $\mathrm{Co}$ (II)->Co(III) during the calcination (in oxygen) process to remove occluded organic template molecules[6]. In addition, a closer look at the change in average Co-O distance at different temperatures (see figure 2a), in particular around $350^{\circ} \mathrm{C}$ reveals that there is an initial decrease from $1.93 \AA$ to $1.90 \AA$ and subsequently above $500^{\circ} \mathrm{C}$ it 

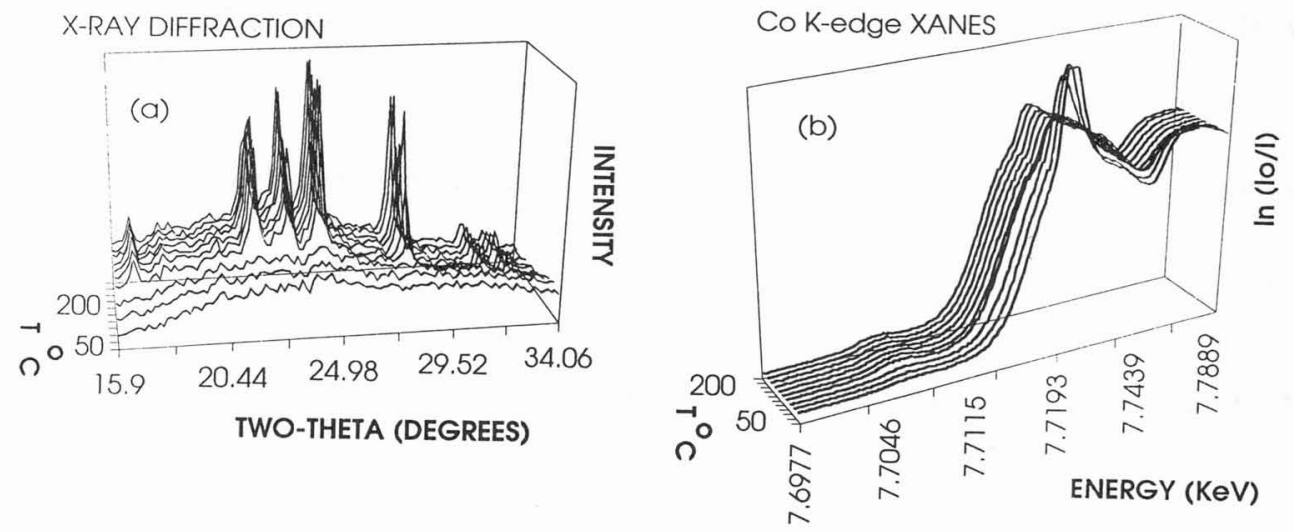

Figure 1. (a) XRD and (b) Co K-edge XANES patterns recorded sequentially employing the experimental arrangement shown in ref 9.

attains a value of $\mathrm{ca} 1.83 \AA$. However, the edge position (scale on the right hand side of the figure) was unchanged (like that of the starting material) until $500^{\circ} \mathrm{C}$, above which there is a distinct positive shift, reflecting an increase in oxidation state of cobalt. Thus the intermediate regime where a slight decrease in $\mathrm{Co}-\mathrm{O}$ distance around the $\mathrm{Co}$ (II) ions is due to the collapse of

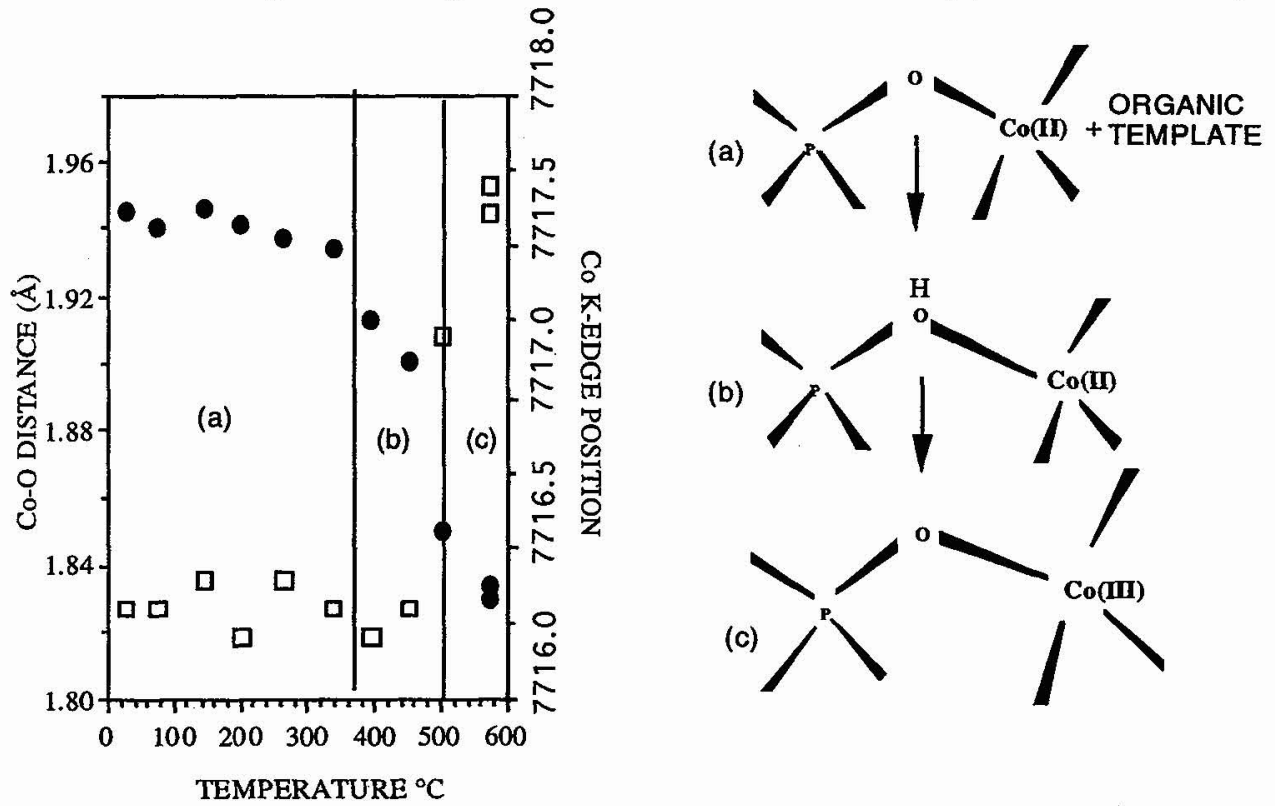

Figure 2. Variation of the average $\mathrm{Co}-\mathrm{O}$ distance (filled circles) and $\mathrm{Co} \mathrm{K}$-edge position (open squares) Vs the calcination (in oxygen to remove occluded template) temperature are shown on the left. On the right, schematic representation of the local structure around cobalt (derived from the analysis of the EXAFS data and IR studies, measured during the calcination process) corresponding to the three regions denoted (a), (b) and (c) on the left of this figure.

charge compensating template leading to protonation (to compensate the negative framework charge which is well supported by the appearance of $\mathrm{OH}$ stretching band associated with Bronsted acid site in the IR spectrum) of the bridging oxygen (Co-O-P) prior to the complete removal the organic template and subsequent conversion of $\mathrm{Co}$ (II) to $\mathrm{Co}$ (III) above $500^{\circ} \mathrm{C}$. This

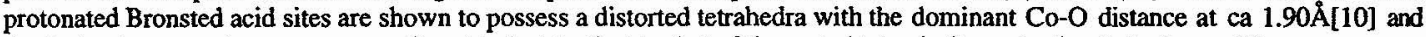
the derived structural parameters are found to be identical to that of the one obtained after reduction in hydrogen[6]. 


\section{Acknowledgements}

We thank EPSRC for financial support and CCLRC for the provision of facilities at Daresbury Laboratory

\section{References}

[1] Thomas J.M., Angew. Chem. Intl ed 33 (1994) 913

[2]. Couves J.W, Thomas J.M, Waller D.W, Jones R.H., Dent A.J., Derbyshire, G.E., Greaves, G.N., Nature 345 (1991) 465

[3]. Clausen B.S , Graback K, Steffensen G., Hansen P.L., Topsøe H, Catal Lett 20 (1993) 23

[4] Thomas J.M., Greaves, G.N. Science 265 (1994) 1675

[5]. Thomas J.M, Greaves G.N and Catlow C.R.A, Nucl. Instrums. Methods B 97 (1995) 1

[6] Thomas J.M., Greaves G.N., Sankar G., Wright P.A., Chen J., Dent A.J, Marchese L, Angew. Chem. Intl. ed. 33 (1994) 1871

[7]. Barrett P.A., Sankar. G., Catlow C.R.A., Thomas J.M., J. Phys. Chem. Solids 56 (1995) 1395

[8]. Sankar G., Thomas J.M, Rey F., Greaves G.N., J. Chem. Soc. Chem. Commn. (1995) 2549

[9]. Pickering I.J., Sansone M., Marsch J. and George G.N, J. Am. Chem. Soc 115 (1993) 6302

[10] Barrett, P.A, Sankar G., Catlow C.R.A and Thomas J.M, J. Phys. Chem 100 (1996) 8977 